\title{
Weak thought, democracy and religion. A decolonial approach
}

\author{
Frederico Pieper* \\ "It is one thing to deconstruct Western metaphysics \\ while inhabiting it, and it is quite another to work \\ on decolonization as a form of deconstruction, \\ from the exteriority of Western metaphysics; that is, \\ from those places that Western metaphysics transformed into \\ 'silenced societies' or 'silenced knowledges"' (Walter Mignolo). \\ "A boundary is not that at which something \\ stops but, as the Greeks recognized, the boundary \\ is that from which something begins \\ its presencing. (Martin Heidegger)
}

\begin{abstract}
Weak thought as elaborated by Gianni Vattimo radicalizes hermeneutics when it recognizes its nihilist feature and as philosophy of praxis. However, this radicalization does not go far enough, once it fails to reach the borders. It still remains circumscribed to a self-referenced identity, which conceives democracy and modernity as a process of reducing violence. For this reason, it is necessary to consider the weak thought from the in-between place of borders to point that modernity does not constitute itself by itself. This form of democracy, far from being a process of reducing violence, may result in exporting violence to other places. It creates those non-places where violence can have a free flow. With these critical remarks, I argue that if we do not recognize the violent facet of the constitution of democracy and modernity, weak thought will hardly be able to adequately interpret the challenges of authoritarianism and fundamentalism of our times.
\end{abstract}

Keywords: Decolonization, Being, metaphysics, Gianni Vattimo.

* Professor at the Departament of Religious Studies of Federal University of Juiz de Fora (Brazil). Doctorade in Religious Studies by Universidade Metodista de São Paulo (UMESP) and in Philosophy by Universidade de Sao Paulo (USP). 


\section{Pensamento fraco, democracia e religião. Uma abordagem decolonial}

\section{Resumo}

O pensamento fraco radicaliza a hermenêutica quando reconhece sua vocação niilista e como filosofia da práxis. No entanto, essa radicalização não vai longe o suficiente, uma vez que não chega às fronteiras. Ela ainda permanece circunscrita a uma identidade autoreferenciada, que concebe democracia e modernidade como processos de redução da violência. Por essa razão, é necessário considerar o pensamento fraco a partir do entrelugar da fronteira para apontar que a modernidade não se constitui por si mesma. E que a democracia, longe de ser um processo de redução de violência, acaba por exportá-la para outros lugares. Ela cria não-lugares onde a violência encontra fluxo livre. Com essas considerações críticas eu espero enfatizar que se não reconhecermos a face violenta da constituição da democracia e da modernidade, o pensamento fraco dificilmente será capaz de interpretar adequadamente os autoritarismos e fundamentalismos de nossa época.

Palavras-chave: decolonização, ser, metafísica, Gianni Vattimo.

\section{Pensamiento débil, democracia y religión. Un enfoque decolonial}

\section{Resumen}

El pensamiento débil (pensiero debole) radicaliza la hermenéutica mediante el reconocimiento de su vocación nihilista y como filosofía de la praxis. Sin embargo, esta radicalización no es suficiente, ya que no llega a las fronteras. Todavía permanece confinado a una identidad autorreferencial, que ve la democracia y la modernidad como procesos para reducir la violencia. Por lo tanto, es necesario considerar el pensamiento débil de la frontera para señalar que la modernidad no está constituida. Tal democracia, lejos de ser un proceso de reducción de la violencia, acaba exportándola a otros lugares. No crea lugares donde la violencia fluye libremente. Con estas consideraciones críticas, espero enfatizar que, si no reconocemos el rostro violento de la constitución de la democracia y la modernidad, el pensamiento débil difícilmente podrá interpretar adecuadamente los autoritarismos y fundamentalismos de nuestro tiempo.

Palabras clave: descolonización, ser, metafísica, Gianni Vattimo.

\section{Introduction}

Borders establish limits. From a geographical point of view, it marks the edges of neighborhoods, areas, cities, territories, and countries. At first glance, borders seem to be a cartographic concept. In some cases, they determine how far someone can go or how certain lines that cannot be surpassed. Being on the border is to go to the margins. One is no longer in the center, from which space and difference are organized. The place now is that of the threshold of the contact with the other side. 
But if the first understanding of the border is cartographic, the border certainly goes beyond mere spatial beacons. After all, how do we understand boundaries (even geographic ones) without considering time? How do we apprehend its formations if we do not take into account the multiple games of power that have determined choices? The border is not something that happens in isolation. As it demarcates, it is the place par excellence for the relations. For this reason, While border functions as a limit, the border points to another beginning. This is due to its constitutively relational character. A border exists in this in-between. It is not exactly one territory or another, but it is part of both. Or rather, the border is what makes a territory recognizable as such. Perhaps, the border is the condition of possibility for a territory. More than a limit, it is the in-between where relationships are most intensely experienced.

What happens to thought when we try to place ourselves in that inbetween? In this case, it is not just a matter of taking the boundary as an object of thought. We are not proposing to think about the border, but to think from that fissured place. Not an object, but a perspective.

The critique of metaphysics, also presupposed in evoking the border as a place of thought, is an insurmountable topic of our time. This is noticeable in the recurrence of the topic, which includes several key contemporary thinkers, whose thoughts and solutions do not necessarily agree with each other. But, however abstract the philosophical formulations may seem, metaphysics and its consequences are also manifested in our daily lives. Nihilism, authoritarian governments, the thechnocratic society or even the ecological crisis can be interpreted as the ultimate expression of the end of metaphysics. For this very reason, if thought wants to be more than a mere history of philosophy (only as a commentary on texts canonized by a certain tradition), or more than justification for the positive sciences, it is in the critique of metaphysics that it finds its most own possibility. In these issues lie the future paths for philosophy.

This perception was already present when Gianni Vattimo proposed in 1983 with other Italian thinkers what has been known as "pensiero debole" (Vattimo, 2012). Weak thought was a way of making sense of the overcoming of metaphysics and finding other ways to think beyond it. Later, several of these early proponents have moved away from this philosophical school (see Eco, 2007, p.37-56). Vattimo, however, has remained a faithful squire of weak thought, drawing its consequences for particular areas of life, such as science, religion, politics, aesthetics, etc. Its strand of weak thought is 
based on a hermeneutic approach that explores the consequences of the radicalization of the interpretative feature of our being-in-the-world for philosophical discourse and rationality. In the 1990s, Vattimo had a greater concern with the topic of religion, particularly with the role of Christianity in a secularized society. From the 2000s onwards, his concept of weak thought has unfolded on ethical and political issues based on the question of how to ground critical attitudes and ethical-political commitments at the time of the dissolution of reality and the end of truth. These phases are intertwined, although each of them has its own highlights.

Taking these developments of weak thought into account, I propose from this in-between place of the borders a critical analysis for the conception of modernity and democracy elaborated by weak thought. First, we consider weak thought's defense of modernity as a process of pacification and reduction of violence. Once modernity happens in a horizon opened by Christian kenosis, it represents a movement towards the reduction of metaphysical truth and hence of violence. Furthermore, weak thought leans on a conception of modernity as a strictly European phenomenon, closed in itself. However, to what extent can this reading of modernity by Vattimo be kept when analyzed from its darker side, from the borders of coloniality? Was there a reduction of violence or was it exported to other places? With this approach of weak thought, I intend to explore the paths that it has opened, but that it does not go through.

\section{Radicalizing Hermeneutics: Nihilism and Philosophy of Praxis}

"[I]n its nihilistic version-as a radical philosophy of praxis, hermeneutics fully recovers its religious origin and its political origin" (Vattimo, 2016, p. 148). Hermeneutics as a philosophy of praxis and, perhaps, as a practical philosophy. This may sound quite weird to the ears of those who are used to thinking of hermeneutics as a theory of interpretation. This becomes much stranger when we consider some prominent names in this tradition. Martin Heidegger was criticized by Theodor Adorno for getting lost in the jargon of Being and for elaborating an evasive discourse of the practice and to promote the reification of bourgeois perspective (Adorno, 1973, p.80). Given this, how can one understand hermeneutics as a philosophy of practice?

Weak thought draws from the hermeneutics some nihilistic implications which were not carried forward by the thinkers who are part of this philosophical scene. In other words, when weak thought radicalizes 
hermeneutics by extracting its nihilistic consequences (Grondin, 2007, p.203216), its realization as a philosophy of praxis becomes evident. Therefore, there is a double movement of radicalization of hermeneutics: its nihilistic assumptions are pulled from it, and subsequently, it is recognized as a philosophy of praxis.

What does nihilism mean in this context? In the proposition of weak thought elaborated by Vattimo, nihilism does not have a negative connotation. Rather, nihilism represents our only alternative that overcomes metaphysics and its aftereffect. So, weak thought assumes that nihilism is the structuring axis of the history of Being. There is an inversion of the sign. If nihilism for Friedrich Nietzsche is a condition to be overcome through the creation of new values, nihilism for weak thought is the means to get out of metaphysics. ${ }^{1}$

When the end of metaphysics is mentioned, we are not facing a simple thing: "[O]ne can simply equate the end of philosophy as metaphysics with the affirmation, practical and political, of democratic regimes. Where there is democracy, there cannot be a class of the holders of the 'true' truth who either exercise power directly (the philosopher-kings of Plato) or provide the sovereign with rules for his behavior" (Vattimo, 2016, p.155; see also Vattimo, 2004, p.83-84). Weak thought maintains that metaphysics stands as an obstacle to democracy. In another elaboration: only when the notion of reality is mitigated or the concept of truth as correspondence to a state of affairs is abandoned, it is possible to bear democracy (Vattimo, 2011, p.23). Once democracy cannot be established without a deep change in rationality, we see the strong link that connects the critique of metaphysics and the ethical and political issues.

It is not a matter of enacting priority of theory over practice, or vice versa. When one of these situations happens, we have problems. When practical dimensions of life are reduced to pre-existing theories, tendencies to rely on dogmatic impositions take place. On the other hand, to conceive theory as mere means for practice is to cut down the critical power of reflection. So, when hermeneutics presents itself as philosophy of practice, it is not intended for the reification of the polarity between theory and practice or to keep one side and dismiss the other. Rather, there is reconfiguration

According to Vattimo's own words: "Hermeneutics is the thought of accomplished nihilism, thought that aims to reconstruct rationality in the wake of the death of God and opposes any current of negative nihilism, in other words the desperation of those who continue to cultivate a sense of mourning because 'religion is no more"'(Vattimo, 2004, p.XVI). 
of the hermeneutic circle: theory and practice must be understood in a circular manner, so that through the interpretive movement both of them are constantly and mutually transformed. Even when hermeneutics is conceived as the theory of interpretative horizons or the conditions of possibilities of being-in-the-world, it does not leave aside the practical dimension of existence. This is so not only because Heidegger conceived the instrument as the most basic way of the Dasein's approach to beings, ${ }^{2}$ but also because hermeneutics is dedicated to the structures that make experience possible in general. In this direction, can the philosophical hermeneutics become even more radical? Can some structures (such as race, gender, society, etc.) not only be the object of analysis, but also be recognized as ways of seeing, ways of constructing meaning, or ways of inhabiting the world? $?^{3}$ With this, we have not yet answered some of the basic questions: how are metaphysics, nihilism and democracy related each other? Considering this bond between theory and practice, what could be a contribution of weak thought for understanding democracy in our contemporary world?

Taking this relationship between theory and practice in account, it is not enough to remain at the level of mere historical description for the construction of an "ontology of the actuality." To understand our time, it is necessary to start from the dimension of praxis. However, we must pay attention to the relationships between this dimension and the ontological constructions that underlie it. In order to reach a reasonable concept of democracy (and how authoritarian positions have gained territory in the actual scenario), it is necessary to consider the notion of metaphysics. I am not referring merely to a branch or a specialty of philosophy. Rather, it is a mode of rationality. Metaphysics "is the idea that, at the basis of things, there is a stable order, a structure necessary, eternal, and hence rational, which it is our task to gain knowledge of and adopt as a norm" (Vattimo, 2004, p .74). Thus, metaphysics is constituted by the belief in an ahistorical and objective order that can be grasped by reason and expressed by language, becoming the rule. To make this possible, it is conceived that the Being has a stable structure, and on the other hand, the subject who knows it has a privileged access to the Being; that is, this subject assures itself on a foundation - a

\footnotetext{
2 "However, as we showed, the closest kind of association is not mere perceptual cognition, but, rather, a handling, using, and taking care of things which has its own kind of "knowledge"” (HEIDEGGER, 2012, \$15, p. 63)

This is a movement underway in phenomenology. See, for example, Weiss; Murphy, Salamon, 2020 .
} 
stable, safe and regulating place - from which the apprehension of this structure is carried out.

Now, to attribute a stable structure to Being means to deny a fundamental feature of human existence: its historicity and the consequent temporality of the Being. Since for metaphysics, temporality is only a structure of Being (and not the structure), the concept of Being as presence becomes absolute, whose properties can be described and represented (Vattimo, 1989, p.18-19). This ontology, as long as it also becomes a search for the cause of Being, finds its final goal in the entity who has the most perfect Being. This being is independent and continuous presence (Anwesenhei) from and in itself: pure $\dot{\varepsilon} v \varepsilon \dot{\varepsilon} \gamma_{\varepsilon} \propto$ (Heidegger, GA22, 2004, p. 178). With this movement, the question of Being turns into the question of the being on which all beings depend and which has Being in its most proper sense. With this movement, the ultimate foundation is achieved. This logic operation effaces the ontological difference, since Being and being are overlapped (Vattimo, 1993, P.163). Thus, the notion of Being as presence leads and is reinforced by the establishment of ultimate foundations. These ultimate foundations have taken on many designations in the history of thought: God, subjectivity, reason, conscience, and so on. ${ }^{4}$

This movement towards ultimate foundations is made with a purpose: the domination of all beings, which has been made explicit at the time of the technique. In this approach, therefore, metaphysics is not something of specialized interest, but it is a way of thinking that is anchored in ultimate foundations and which most fulfilled and brutal configuration has been the technological domain of beings. Due to this ontological background, it is not sufficient for historical or sociological explanations to understand the

\footnotetext{
4 Accordingly, Jacques Derrida says: "The history of metaphysics, like the history of the West, is the history of these metaphors and metonymies. Its matrix-if you will pardon me for demonstrating so little and for being so elliptical in order to come more quickly to my principal theme-is the determination of Being as presence in all senses of this word. It could be shown that all the names related to fundamentals, to principles, or to the center have always designated an invariable presence-eidos, arche, telos, energeia, ousia (essence, existence, substance, subject) aletheia, transcendentality, consciousness, God, man, and so forth" (Derrida, 2001, p.253). “(...) in the course of the history of metaphysics from Plato on, presence becomes rigidly identified with the pure being present of what is present; no further attention is paid to the 'eventual' character of presence, until presence is in the end totally reduced to abjectness, to the Bestand of technology as accomplished metaphysics (Vattimo, 1993, p.116-117)
} 
technique. Its roots are located in ontology. To be more precise, it is located in this overlap between Being and beings that outline metaphysics. And metaphysics has achieved its ending not because it has lost the game. Rather, it comes to an end when it fully realizes its intentions of dominance over beings. It comes to an end because it has been fulfilled.

Given this brief picture, what does it mean to say that nihilism provides a kind of redemption? And, to return to our topic, what does the critique of metaphysics have to do with democracy? Weak thought identifies three facets of nihilism, though all of them have a common denominator. In contrast with the realistic impulse that distinguishes metaphysics, it highlights the situated and the interpretative character of our dwelling in the world. In a nutshell, nihilism denotes that we do not have access to such a structure of Being but that our way of dwelling the world is an interpretive one. It is not just a matter of "knowing the world," but of "dwelling in it." After all, it is not only a cognitive act, but a way of placing oneself in the world: a mode of existence. Because of that, we are trapped in the network of meaning and interpretations that are historically built which we have inherited. This does not mean that such network holds us in such a way that we are immobile. There is a certain malleability. But we think from this inherited network of meanings. To express in a more systematic way, the three aspects of nihilism are: a) "everything is interpretation," b) "this is already an interpretation," and c) nihilism is the structuring axis of the history of Being.

The Being that enables beings to come to the light and manifests themselves is this inherited network of meanings, that is, language. To dwell in a world is to dwell in a language. Language does not have the sense of the grammatical or neurofunctional structures; but it is a historically constructed heritage that constitutes the horizons in which beings come to meet human Dasein. This recognition brings us to Nietzschean terms: "everything is interpretation." So, we have always been involved in a network of meanings (language) that enables and limits us to a certain way of access to the beings.

However, Vattimo would not be radical enough if he also did not assume the complement of Nietzsche's saying: "this is already an interpretation" (Nietzsche, 1996, \ 481). In other words, weak thought not only assumes that everything is interpretation, but the very affirmation of the interpretative character of our knowledge does not escape from this character. Behind the interpretation, there is no stable subject who can centralize and organize the dissemination of conflicting interpretations. Thus, weak 
thought assumes that everything is interpretation, including this statement, collapsing any attempt to attribute any pre-hermeneutical stability to Being. Therefore, affirming the interpretative character of our being-in-the-world does not mean that we now know how things are. This very statement does not get away from being considered as interpretation. If this solution avoids the contradiction, on the other hand, it brings up a very complex problem: is weak thought a kind of relativism? If everything is interpretation (including this sentence), and what is the criterion for classifying certain interpretations as fair and others as attempts of domination? If there are no ultimate grounds, is everything allowed? After all, would hermeneutics lead to irrationalism?

In order not to fall into irrationality or relativism, it is necessary to consider the third aspect of nihilism. In addition to the recognition of the radicality involved in the interpretative character of our dwelling the world, nihilism also involves the history of Being. Weak thought is rooted in the way it reconstructs the history of Being by taking the weakening of the strong structures of metaphysics (nihilism) as its logic. This means the building of an interpretation that allows us to make sense of a certain heritage from our insertion in this story. It is not a question of assuming a necessary "destiny" for history, but of constructing an interpretation able to significantly articulate this horizon, this heritage, and our place in it. From this point of view, the history of the West as attached to the history of Being is interpreted as aiming towards weakening the strong structures of metaphysics. With this, we have the criterion for differentiating acceptable and problematic interpretations: in what sense are they inserted and promote the weakening of the strong structures of metaphysics? In fact, it is not a coincidence that in his most recent texts, Vattimo has emphasized the dismissal of the notion of truth or the criticism of the idea of reality (Vattimo, 2010; 2011; 2016; Vattimo, Zabala, 2011.). All of these are, at the bottom, formulations for the basic principles of what has been metaphysics as a manifestation of this history of Being. ${ }^{5}$

This notion is quite an important difference between weak thought and deconstruction. The hermeneutic insertion in a set of messages sent by the past (Ge-schik) and that gives shape to a history of Being avoids a purely aesthetic approach to thinking after the death of God. Vattimo argues that after a fall of the ultimate foundations, we have a story, a message to answer. This history is a history of Being, which is also metaphysics. The metaphysics, therefore, is not simply a mistake that must be unmasked, but it is a way of how Being happens. Jacques Derrida falls into this estheticism precisely because 
In other words, the radicalization of hermeneutics leads us to the acceptance that there is no access to the structure of Being as such, but only interpretations from a historically constructed horizon (of an opening). Since his first writings, Vattimo uses a very appropriate expression to express this perception: hermeneutical foundation (Vattimo, 2012, p. 40). Then, it is not a matter of mere relativism; there is a foundation. However, it does not claim to be necessary and unhistorical as the metaphysical foundation. As it is deeply immersed in temporality, it is a hermeneutical one.

What, then, allows Vattimo to equate the end of metaphysics (also expressed as farewell to the truth or dissolution of reality) with the affirmation of democratic regimes? In fact, is it not the destruction of the notion of truth one of the big problems in democratic regimes today? Metaphysics can be said to be undemocratic because it is grounded in ultimate foundations, imposing silence and making dialogue impossible. As a result, it is imbued with violence. 'Truth is not only 'violent' in that it turns away from solidarity, but it is 'violence,' because it can easily become an imposition on our own existence. Being 'violent' might imply that it can also be peaceful, but truth instead often implies an imposed description whose acceptance is assumed. Violence is the political meaning of truth" (Vattimo, Zabala, 2011, p.18).

For this reason, the proposal to overcome metaphysics does not arise from the eminently epistemological or theoretical problems. Rather, the need for overcoming metaphysics is due to practical reasons: it is intrinsically violent. This polysemic word takes on a very precise meaning in weak thought: violence is the silencing of the other. It is denied to the other the existence as long as he/she does not have granting the right to interrogate or speak owing to the impositions by an authority that sees itself as legitimized on ultimate foundations. In Vattimo's own terms, "I use 'violence' to mean the peremptory assertion of an ultimate that, like the ultimate metaphysical foundation (or the God of philosophers), breaks the dialogue and silences the interlocutor by refusing even to recognize the question "why" (Vattimo, 2004, p.98) ${ }^{6}$. It is important to note that the

it considers that to get out of metaphysics it is necessary to abandon questions about Being and its history. "If it is not the story of the history of (the dissolution of) Being, deconstruction seems to be an ensemble of conceptual performances entrusted to the sheer artistic flair [genialita] of the deconstructor" (Vattimo, 1997, p. 12).

6 There are similar definitions in other Vattimo's writings. "Rather, it is as a thinking of the incontrovertible presence of Being - as the ultimate foundation before which one can only fall silent and, perhaps, feel admiration - that metaphysics is a violent thinking: the 
critique of metaphysics is not only motivated by ethics, but more than that: the ethics is akin to the possibility of establishing and keeping a dialogical attitude. Even so, the basic violence of metaphysics lies in the interruption of dialogue. Since the claim to the structure of Being or to the authority of ultimate foundations is not recognized as an interpretation, it implies silencing the divergent and eliminating the possibility of questions. In this sense, it shows itself as the original form of other kinds of violence. After all, when someone believes that he/she has the true order of things, he/ she should only communicate this truth to others. It is a duty. A moral obligation to convince others of this truth. In this way, the matrix form of violence is found in the silencing by resorting to the ultimate structures and foundations. From this ground, it is possible to legitimize all forms of abuse in relation to others.

So, when weak thought criticizes the notion of truth, it does not think of a simple abandonment of the notion of truth, but a reconfiguration of it. Instead of the conception of truth as an imposition of one perspective over others, truth it is a dialogical construct. Since it is a dialogical construction, it requires responsibility from those who take part in this (Vattimo, 2010, p.63). The truth is not ever settled, but it is built in dialogue in the midst of the conflict of interpretations. Conflict that should not be brought back to agreement, but it can find points of articulation. For this reason, Vattimo affirms that the human being who can live in a contemporary democratic society is the Nietzschean Übermensch. This citizen is the overman, since he/ she lives in-between several interpretations without assuming one of them as a definitive one (Vattimo, 2002, p. 203).

To sum up, since metaphysics call for the legitimacy of a principle that imposes itself in an authoritarian way, it does not fit in with democratic principles. For this very reason, the critique of metaphysics is tantamount to the establishment of democracy. With this we can understand how

foundation, if it is given in incontrovertible evidence that no longer admits further enquire, is like an authority that keeps things quiet and takes control over explanation" (Vattimo, 1997, p. 31). Or still: "If there is a true nature to things, there is always an authority - the pope, the party, the'objective 'scientist, etc. - who knows it better than I do and who can also impose it against my will. What is the use of insisting on objectivity and the reality of the truth if not to guarantee the authority to someone?" (Vattimo, 2001, p. 30). "If truth claims are also always claims of political power, that is, violence, and if this same violence is nothing else than the "silencing" of other interlocutor through an apparent dialogue, truth and violence become interchangeable" (Vattimo, Zabala, 2011, p.18). 
hermeneutics when recognizing itself as philosophy of praxis is able to recover its political origins. But, what about the religious origin?

Regarding this, weak thought pursues the recovery of a structuring element from the Western historical horizon: kenosis. Particularly during the period when Vattimo was a member of the European Parliament, he has dedicated himself to the reflection about Europe's identity. In this moment, Christianity occupied an important role in his proposals. Although his main concern was to demonstrate how Christianity inaugurates a framework of references that is decisive for the Western hermeneutic horizon, in many ways his approach to religion was almost theological. For Vattimo, since Christianity affirms that God made himself human through Jesus, we come across the notion of a God who takes weakness as a possibility. This episode has opened up this epoch of the weakening of Being and it is the nihilist element within metaphysical tradition. The history of Being is marked by this tendency to put in question the rigid and authoritarian notions of truth due to the gospel principle of a God who becomes a human. Because of that, weak thought gives support to a comprehension that highlights the ethical feature of Christianity as part of the Western frame of references. ${ }^{7}$

From a scientific or even some religious point of view, there is a prevailing perspective that understands secularization as a departure from religion. In this sense, modernity would represent the "other side" or a dismiss of Christian religious beliefs, practices, and worldview. According to this perspective, secularization is the process in which religion loses its role as an articulator of social life, to become one more social sphere alongside others. As a result, not only do religious symbols lose their social and cultural importance, but society itself deviates from the religious matrix. However, for weak thought, there is no such opposition between modernity (secularization) and Christianity. Quite the opposite. Since Christianity is this tendency to the weaken of the strong structures of metaphysics, modernity would be nothing more than a deepening of the Christian message. If the history of the West is the history of the weakening of Being inaugurated by Kenosis, it does not make sense to distinguish profane history from the religious one.

It is important to notice how weak thought has inspired some theological perspectives. In 2006, influenced by these ideas, John Caputo published the book The Weakness of God, in which he gives some development to a Weak theology. Recently, Gustavo Gutiérrez has recognized the contributions of weak thought to a theology from Latin America and is concerned with the poor (Gutiérrez, 2005, p.140). 
Then, "In other and more provocative words: I mean that today the West, understood as the land of the sunset and of weakening, is Christianity's truth" (Vattimo, 2002b, p. 80).

We still shall return to this polemic quote. For now, it is important to notice that Vattimo supports a normative understanding of both democracy and Christianity. He is doing this when he pulls the hermeneutics as a philosophy of praxis back to its political and religious origins. When I say that we are facing some normative propositions, I understand normativity not as indicating what something must necessarily be, but what something could be. Thus, when Vattimo understands that Christianity is best characterized by weakness and love, or democracy by dialogue that intends to build truth, one should not understand that he is offering a description of religion in current historical conditions. Indeed, he is very critical of certain positions of the Catholic Church or of authoritarian political decisions. Rather, his intention is to indicate the potentialities that Christianity and democracy have. Both possess elements in their hermeneutic horizon that would make this other configuration possible. And the normative approach explores those possibilities. And the normative as possibility works as a criterion for the establishment of criticism to the historical forms of democracy and Christianity. If we take their propositions as descriptions, they sound, to say the least, naive. After all, while he speaks of Christianity as the responsible for the weakening of metaphysical structures, the religious form of Christianity that stands out most in the twentieth first century is that of fundamentalisms. Nothing is more metaphysical than this kind of religiosity in our time. This is the reason why they recognize and ally themselves with metaphysical and anti-democratic governments (with forgiveness for pleonasm) in current politics: the far-right ones.

This consideration, however, should not be used as an excuse for the treatment of fundamentalism. ${ }^{8}$ It has received little attention from

"(...) It is not hard to see them as neurotic defenses of identity and belonging in reaction to the infinite widening of horizons entailed by the culmination of the epoch of the world picture. Without a clear appropriation of its own nihilistic vocation, hermeneutic ethics can only respond to this situation by seeking to contain it, as if it were essentially a matter of defending a kernel of values that are under threat and inexorably destined to be swept away. This, on close inspection is the tenor, the Stimmung, of hermeneutics' humanism's attitude towards the techno-scientific Society (...).Instead of reacting to the dissolution of the principle of reality by attempting to recuperate a sense of identity and belonging that are at once reassuring and punitive, it is a matter of grasping nihilism as a chance of emancipation" (Vattimo, 1997, p. 39-40). See also Vattimo, 2004, pp. 91-92; and 1998, p.83). 
weak thought. They have been very fast called as a neurotic and defensive reaction to the plurality of today's world. The lack of ultimate foundations can build overmans, but also cause resentment in people who neurotically cling to ultimate foundations. They are called neurotic because more of their foundations are threatened, more strongly and violently fundamentalists tend to cling to their foundations.

Why do perspectives that claim ultimate foundations sound so attractive at the time of God's death? Are they simply signs of neurosis (as Vattimo often designates it) or are they symptoms of deeper things? Could, for example, the return of religion with this fundamentalist tone indicate a certain limit in the Nietzsche's announcement of the death of God? According to the Nietzsche's God-foundation thesis, he had the function of organizing the world, providing security to enable social life. However, when the world has become safe, the God-foundation thesis is dispensable. For this reason, Nietzsche could say that God is dead (Vattimo, 2002a, p. 257; 2002b, p. 12; Rorty e Vattimo, 2005, p. 74). We should consider the persistence of this thesis from another point of view. Would not the return of fundamentalism and the affirmation of a moral God be related to the unsafe conditions of the current world? Disasters, threats to the continuation of life, attacks, violence, etc. would they not lead to the need to return of the God-foundation? Vattimo does not seem inclined to conceive things in this direction, which would imply a reformulation of his thinking, strongly dependent on Nietzsche.

\section{Radicalizing even More? Moving to the Borders}

Thus, as we have seen, weak thought articulates nihilism and Christianity under the command of overcoming metaphysics and the promotion of democracy. But, let's move to the border. Not only to the border as a limit, but the border as situated on the margins, the inter-between of colonial difference where the global designs meet local histories (Mignolo, Walsh, 2018, p.112; Mignolo, 2000, p. 67). This denotation is very important. The inter-between is this meeting place, with multiple and unpredictable relationships. In this sense, it is not a simple denial of modernity. To think from the borders is not a sort of anti-colonialism. In the same perspective of weak thought, it reveals the situated feature of designs that want to be universal. The modern raises local histories to the status of global designs is nothing else than the absolutization of some finite hermeneutical horizons. This criticism, however, does not mean abandoning the recognition of the impact of modernity and its narratives on 
the peripheries and borders of the world. ${ }^{9}$ In fact, the opposite is true. The point is to recognize how this modernity is also dependent on these margins, although it often forgets itself, or strives to forget it.

Since it emphasizes the finitude and hermeneutic aspect of human dwelling, weak thought criticizes perspectives that deny this situated condition of any enunciation. Vattimo, for example, already in the 1990s, has emphasized this. He has noticed that as long as modernity spreads across the globe and makes the ideal of a universal history possible, this project (of a universal history) proves to be unfeasible. Mainly, owing to the means of communication, the West realized that there were other cultures that were not allowed to be reduced to its logic, that Europe is not the most developed and finished achievement of humanity. In short, "If I profess my system of values - religious, ethical, political, ethnic - in this world of plural cultures, I must also have an acute awareness of the historicity, contingency and limitation of all these systems, starting with my own" (Vattimo, 1992, p. 43). The recognition that the global village is not made up solely of the West has led to a weakening, or even made impossible that reality can be apprehended by an ultimate foundation.

If weak thought has this openness to the other, it does so with earnest limitations. Indeed, it seems that weak thought points to some ways, but does not explore them. If it radicalizes the nihilistic consequences and hermeneutics as a philosophy of praxis, weak thought still seems withdrawn from this radical experience of the borders. Regarding this, weak thought and its interpretation of Christianity builds a mythological version of democracy with a double exclusion: the constitutive violence of democracy as well the forgetting of the other, the darker side of modernity. In this sense, it restores silences (and as we have seen, this is violence). This non-recognition is a way of imposing silence on the other.

Regarding this, Walter Mignolo affirms: "Briefly, I found in all these examples the sense of that border thinking structure itself on a double consciousness, a double critique operating on the imaginary of the modern/colonial world system, of modernity/coloniality. As such, it establishes alliances with the internal critique, the monotopic critique of modernity from the perspective of modernity itself (e.g., Kierkegaard, Nietzsche, Heidegger, Marx, Freud, Derrida) at the same time that is marks the irreducible difference of border thinking as a critique from the colonial difference (...) Border thinking brings to the foreground the irreducible epistemological difference, between the perspective from the colonial difference, and the forms of knowledge that, being critical of modernity, coloniality, and capitalism, still remain 'within' territory, 'in custody' of the 'abstract universals”' (Mignolo, 2000, p.87). 
One of the most powerful forms of effacement of the other is the construction of mythologies. For those who study religion, it is very clear that mythologies are not simple lies or fables. Rather, they undertake the explanation of certain things by offering a vision of wholeness. They have a great legitimating power. Thus, myths are not a description of a state of things. But they make an effort, often referring to a mythical origin, to offer an explanation of why things are as they are. Unlike science, they are not reduced to specific aspects of life, but build panoramic and totalizing views. Once they become consolidated, these explanations and totalizing visions function as a justification for practices, institutions, relations, identities so forth. We should not forget that the history of Being is a sort of mythological reconstruction. But what is forgotten in this story of the forgetting of the Being? While remaining on the surface of exaltation of the pacifying character of democracy, does not this reconstruction restore violence that it used to blame metaphysics? Putting it more explicitly. Considering a certain appropriation of the Christian heritage, weak thought assumes the conception that democracy is organized around pacification and reduction of violence. Moreover, when weak thought couples Christianity with Europe, it gives support to the understanding that democracy is a typically European phenomenon. But, is it possible when we consider modernity from the point of view of the border?

In weak thought, there is an opening to think of democracy as something that is beyond Western societies. However, even if there is this possibility, this understanding is not totally surpassed (Vattimo; Rorty, 2005, p.72; Vattimo, 2010, p.61). As Vattimo says, "The West, feeling the exigency of affirming its own cultural identity (...) does not find unifying and identifying elements other than, in a secularized form, a shared Christian origin" (Vattimo, 2002, p.74). These and other statements that identify Christianity with Europe and reduce democracy to the inner level of Western societies is a sign of how weak thought does not surpass Eurocentricism. It is as if European society and culture is closed in itself, confined within the limits of its own territories and story. In this case, the border is not an openness to another, but a limit that is closed on itself. It is true that one of the biggest issues of metaphysics is the objectiveness and the ultimate foundations. But Heidegger warns us throughout his writings that being is not a substance, but it is a relation. The ready-to-hand entities presupposes a remissive background. Even in his later writings, when Heidegger talks 
about the divines, mortals, earth and sky, he always emphasizes that the beings are in relation.

Now, what about the "darker" side of this story? Is it possible to understand modernity without taking into account its double: coloniality? At this point, it is worth recalling a fundamental contribution from phenomenology. The whole process of construction of subjectivity passes through the other. In other words, subjectivity is intersubjectivity. Thus, the construction that an individual makes of his/her identity passes through intersubjective relations. It is a well known passage from Sartre's Being and Nothingness in which he describes how the gaze of the other steals my being, and at the same time thi gaze constitutes myself (Sartre, 1984, p. 340). Therefore, no identity-building process takes place without establishing a relationship with another. As this other participates in this construction, the other becomes part of that identity.

Thus, it is no coincidence that, at the moment in which the biggest European empires are constituted through territorial expansion and conquest, democratic regimes are implemented on the European continent. This colonial system is not a mere externality or consequence of modernity, but it is at its heart. This coloniality runs through economy and politics, and also through culture. What makes modernity not a typical European phenomenon is that it could not be carried out without this obscure face. If we consider modernity from the mythology of the weakening of the strong structures, it is a European phenomenon. But, in a broad sense, modernity takes on a planetary connotation. It affects even the ends of the earth. And Europe builds its own identity in the relationship with this other, particularly in the way it conceives this other. Regardless of how Europe differs itself from this other, appropriates it or effaces it. Without considering this other, modernity and the conception that it represents, a reduction of violence through democracy tends to assert itself as a form of imperialism or even triumphalism. The previous claim by Vatttimo's that secularized Europe would be the fullest realization of Christianity is not just a controversial claim. It is an evidence of how ignoring coloniality can lead to a certain triumphalism. Particularly, in a period in which there are attempts to understand Christianity as a plural phenomenon. ${ }^{10}$

${ }_{10}$ Dale Irvin, for example, defines the field of Studies called World Christianity as "the study of World Christianity seeks to investigate and understand Christian communities, Faith, and practice as they are found on six continents, expressed in diverse ecclesial traditions, and 
If the triumphalism of this kind of posture is more evident, it hides yet another feature even more harmful. This exclusion of coloniality is a reification of the discourse that affirms democracy and modernity as peacemakers. The point is not only that it is necessary to consider coloniality, but how it takes place in this system. As we might see, this kind of view hides the violence that constitutes democracy.

So, to what extent does this type of construction not work as a reinforcement for the idea that modernity and democratic societies would be pacified societies, that is to say distinct from warrior societies? Indeed, often using René Girard, Vattimo makes this distinction in religious terms. The weakening Christian God differs from the deities of natural religion. This kind of religion is metaphysical, affirming a natural and violent conception of deity. Christianity here would seem to represent the overcoming of this relationship with divinity, conceiving God as a friend (Vattimo, 1997, p. 50-51). But, is that so? Would not violence remain at the heart of the constitution of modernity and democracies?

At the end, it seems that this pacifying discourse works based on the hiding of violence that constitutes modernity and democracy. This picture becomes clearer only when we consider coloniality as constitutive of modernity. The violence and brutality of modernity are not pacified, but are exported and outsourced. Achille Mbembe remembers this process and gives a name to those territories to where violence is exported: "non-places" or "third places." In the colony, to where the unwanted ones were sent, the legal system works based on certain suspensions. Here, the sovereign can violate and kill assured of his impunity. The violence and violations questioned in the metropolises could find free flow in colonies. "The cost of the mythological logics required for modern democracies to function and survive is the exteriorization of their originary violence to third places, to nonplaces, of which the plantation, the colony, or, today, the camp and the prison, are emblematic figures" (Mbembe, 2019, p. 27).

informed by the multitude of historical and cultural experiences in a world transformed by globalization. It is concerned with both the diversity of local expressions of Christian life and faith throughout the world, and the variety of ways these interact with one another critically and constructively across time and space. It is particularly concerned with marginalized experiences or expressions of Christian faith that have been underrepresented in scholarship and underappreciated for their wider contributions" (Irvin, 2016, p.04) 
This understanding coming from the borders broadens our horizons. After all, the colonial model does not refer to the historical past, to the epoch of the building of modernity and democracy. In fact, the colonial matrix is our past, present, and future. These non-places are replicated in spaces where life is exposed without mediation: be it the concentration, the refugee camp, the prisons, the slums, and so forth. Instead of being the reverse of democracy, would these places of exclusion not be implicit in it? Would they not be a crucial part for keeping this "pacifying" character of democracy working? Within the colonies themselves this is reflected in how occupation of space is organized. Cities are arranged to create and keep the segregation and the hierarchy between who has rights and who has just the "bare life." In these contexts, democracy as dialogue and the overcoming of violence is merely an abstraction.

Giorgio Agamben has argued that the concentration camp became the model for the exercise of sovereignty as a state of exception at the end of the twentieth century (Agamben, 1998). In my view, however, Mbembe goes further. It was not the concentration camp, but the colony that was in the first place where these technologies and devices were tested. These territories had and have to bear all the violence that was exported to keep the image of democracy as a peaceful process.

Would not this violence exported to these non-spaces of the colony and their actual correspondents also help explain the resurgence of fundamentalisms at a time when Vattimo projects weak and democratic thought? When I mention fundamentalism, I am not only referring to the religious one, but to authoritarian governments that are taking over democratic regimes. To a large extent, this cursed part, this forgotten or muffled violence comes back and spreads colonial practices on a global scale. This is a face of what can be properly called necropolitics. On the one hand, there is the fictional creation of enemies. For the simple fact that they exist, they are seen as a threat to the established social hierarchy and, therefore, must be eliminated. They are immigrants, blacks, LGBTQ, indigenous, etc. On the other hand, under the argument that in order to preserve democratic rights they must be temporarily suspended, the normalization of the state of exception gives to sovereignty this power to decide who has right to live or die (Mbembe, 2019). If one adopts the reading of modernity and democracy as peacemakers, how can we understand the increasing use of these resources by contemporary democracies? If modernity is only a deepening of the 
Christian message as the weakening, how can we explain the sacrificial logic that governs our lives at the end of metaphysics beyond a characterization of "neurotic"?

With this critique, I am not proposing discarding democracy. Far from it. But, as weak thought seems to imply, the more this violent face constitutive of democracy is hidden, the less it is understandable how explicit forms of authoritarianism gain strength in the contemporary world. It is also clear that authoritarianism is not something opposed to liberalism or neoliberalism, but is rather its darker, nocturnal side. Swept to the non-places. "Almost everywhere the law of blood, the law of the talion, and the duty to one's race-the two supplements of atavistic nationalism-are resurfacing. The hitherto more or less hidden violence of democracies is rising to the surface, producing a lethal circle that grips the imagination and is increasingly difficult to escape. Nearly everywhere the political order is reconstituting itself as a form of organization for death" (Mbembe, 2019, p.06-07).

\section{Conclusion}

If weak thought radicalizes hermeneutics recognizing its nihilistic and practical character, it does not reach the border. It still remains circumscribed to a self-referenced identity, which conceives democracy and modernity as a process of reducing violence. As a constitutive feature of metaphysics, violence is the interruption of dialogue and the silencing of the other. It is true that weak thought recognizes its deep contingency. Consequently, there are interpretations and worldviews that cannot be submitted to a single horizon. However, it does not seem to assume the relational and constitutive character of this border with the same radicality. For this reason, it is necessary to look from the in-between place of the borders to point out that modernity does not constitute itself by itself. And that democracy, far from being a process of reducing violence or incompatibility with metaphysics, brings within it much of that metaphysics in its most brutal sense. The creation of non-places where it can impose itself without proper mediation, freely exercising its violence. With that, I do not intend to dismiss democracy as the most viable proposal. Rather, if we do not recognize the violent face of its constitution, weak thought will hardly be able to adequately interpret the authoritarianism and fundamentalisms of our times. 


\section{References}

ADORNO. T. The Jargon of Authenticity. Translated by Knut Tarnowski e Frederic Will. London: Routledge, 1973.

AGAMBEN, G. Homo sacer. Soverign and Power Bare Life. Transl. Daniel Heller-Rozen. Standford: Standford University Press, 1998.

CAPUTO, John. The Weakness of God. Bloomington, Indiana: Indiana University Press, 2006.

DERRIDA, Jacques. Writing and Difference, Translated by Alan Bass. London/New York: Routledge, 2001.

ECO, Umberto. Weak Thought and the Limits of Interpretation. In: ZABALA, Santiago (editor). Weakening Philosophy: Essays in Honour of Gianni Vattimo. Montreal: McGillQueen's University Press, 2007, p.37-56.

IRVIN, Dale. What is World Christianity? In: TAN, Jonathan; TRAN, Anh W. World Christianity. Perspectives and insights. New York, Orbis books, 2016. P. 03-25

GRODIN, Jean. Vattimo's Latinization of Hermeneutics: Why Did Gadamer Resist Postmodernism? In: ZABALA, Santiago (editor). Weakening Philosophy: Essays in Honour of Gianni Vattimo. Montreal: McGill-Queen's University Press, 2007, p. 203-216.

GUTIÉRREZ, Gustavo. ¿Dónde dormirán los pobres?. In: MÜLLER, Gerhard; GUTIÉRREZ, Gustavo. Del lado de los pobres. Lima, Peru: Centro de Estudios y Publicaciones (CEP), 2005.

HEIDEGGER, M. Being and Time. Translated by Joan Stambaugh. New York: State University of New York Press, 1996.

Die Grundbegriffe der Antiken Philosophie. 2. ed. Frankfurt am Main: Vittorio Klostermann, 2004 (Gesamtausgabe, Band 22).

MBEMBE, Achille. Necropolitics. Durham: Duke University Press, 2019.

MIGNOLO, Walter D. Local Histories/Global Designs. Coloniality, Subaltern Knowledges, and Border Thinking. Princeton: Princeton University Press, 2000.

MIGNOLO, Walter and WALSH, Catherine. On Decoloniality: Concepts, Analytics, Praxis. Durham/London: Duke University Press, 2018.

NIETZSCHE, Friedrich. Der Wille zur Macht. Sttutgart: Alfred Kroner Verlag, 1996.

SARTRE, Jean-Paul. Being and Nothingness. Translated by Hanzel E. Barnes. New York: Washington Square Press, 1984.

VATTIMO, Gianni. A sociedade transparente. Trad. Hossein Shooja e Isabel Santos. Lisboa: Relógio D'água, 1992.

The Adventure of Difference. Philosophy after Nietzsche and Heidegger. Translated by Cyprian Blamires with the assistance of Thomas Harrison. Baltimore: The Johns Hopkins University Press, 1993.

Beyond Interpretation. The Meaning of Hermeneutics for Philosophy. Translated by David Webb. Standford: Standford University Press, 1997. 
. The Trace of the Trace. In: VATTIMO, G.; DERRIDA, J. Religion. Translated by Samuel Weber. Oxford: Blackwell, 1998.

Laterza, 2001

Soffusi e deboli: così li preferisco. In: Attualità dell'illuminismo. Roma-Bari:

Diálogo con Nietzsche. Ensayos 1961-2000. Tradução de Carmen Revilla. Barcelona: Paidós, 2002a. Press, 2002b.

After Christianity. Translated by Luca D’Isanto. New York: Columbia University

. Nihilism and Emacipation. Ethics, Politics, and Law. New York: Columbia University Press, 2004.

. The Responsability of the Philosopher. Translated by William McCuaig. New York: Columbia University Press, 2010.

A Farwell to Truth. Translated by William McCauig. New York: Columbia University Press, 2011.

. "Dialectics, Difference, Weak Thought". In: VATTIMO, Gianni and ROVATTI, Pier Aldo (eds.). Weak Thought. translated by Peter Carravetta. Albany: Suny 2012.

Of Reality. The purposes of philosophy. Translated by Robert T. Valgenti. New York: Columbia University Press, 2016.

VATTIMO, G. e RORTY, Richard. The Future of Religion. New York: Columbia University Press, 2005.

VATTIMO, Gianni; ZABALA, Santiago. Hermeneutic Communism. New York: Columbia University Press, 2011.

WEISS, Gail; MURPHY, Ann V.; SALAMON, Gayle. 50 Concepts for a Critical Phenomenology. Evanston: Northwestern University Press, 2020.

Submetido em: 30-6-2020

Aceito em: $14-8-2020$ 